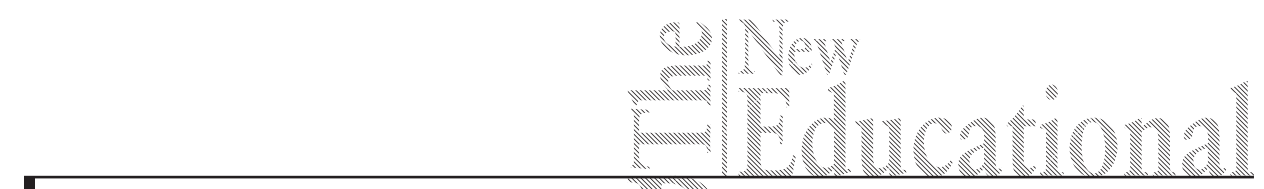

Krzysztof Rubacha, Mariana Sirotova

Slovakia

Mariola Chomczyńska-Rubacha

Poland

\title{
Educational Self-Efficacy in Teachers \\ of Various Ethical Orientations. The Slovak Research
}

DOI: $10.15804 /$ tner.2016.43.1.16

\begin{abstract}
The article provides an empirical analysis of a relationship between ethical orientations and educational self-efficacy. Ethical orientations are defined in the theoretical system of K. Gilligan, whereas self-efficacy is viewed through the social-cognitive theory. The results of the analysis of variance demonstrate the existence of statistically significant differences in self-efficacy between teachers who prefer the ethics of justice and those who prefer the ethics of care, in favour of the former. However, the Eta coefficient shows that the relationship strength is not very large. In conclusion of the result interpretation we explain what our research explicates and what lies beyond its capacity.
\end{abstract}

Keywords: teachers, ethical orientations, educational self-efficacy, care and justice ethics

\section{Issue}

Self-efficacy is considered as one of the key variables that account for acting (Bandura 1994). It is also the case with the educational self-efficacy in reference to teachers. The area of this random variable is filled by a number of factors. Our research concerns one of them, namely ethical orientation preferred by teachers. Both abovementioned variables have a solid theoretical tradition, which we will analyse before the problematization of the presented research. 
Self-efficacy is conceptualized in two ways: personality disposition and situational variable. In the former case it constitutes personal resources of the individual, i.e., cognitive and motivational, which are used to predict the success of acting. These resources create the following: an ability to defer gratification, confidence, developmental motivation, perseverance, an ability to translate objectives into an action plan, immunity to frustration and stress, feeling of authorship, inner-direction (Schoda, Peake 1998, Pervin, John 2002). The higher the intensity of these dispositions is, the higher the self-efficacy is. The second approach, represented by A. Bandura, without contradicting the meaning of disposition, defines self-efficacy as an individual's variable judgement over the capability to rise to the objective challenges of a given situation (Bussey, Bandura 1999, p.691). Based on the previous experience of situations similar to the task at hand one may anticipate the likelihood of solving that task with success. Both conceptualizations constitute attractive ideas for the operationalization of the variable. The dispositional definition allows for the formation of a test that measures respective resources of the individual (Chomczyńska-Rubacha, Rubacha 2006). A. Bandura's approach is often referred to as a micro-analytical approach and it allows for the formation of such a research situation in which a given person under examination forms a judgement on the extent to which he/she will be equal to the formulated task. It is more adequate to employ the micro-analytical approach that derives from the social-cognitive theory in testing educational self-efficacy.

The issue of ethical orientations derives, on the other hand, from the discussion that C. Gilligan had with L. Kohlberg on orientations that steer us into making moral decisions (Gilligan 1998). Kohlberg's theory focuses on justice as a criterion for making mature moral decisions (Kohlberg 1984). In the author's conceptual system this relates to the decisions that constitute solutions to moral dilemmas. As Kohlberg's dilemmas were so designed that their post-conventional solution was based on Kantian ethics of justice, C. Gilligan saw a gap in that reasoning. By quoting the results of her own research, she indicated that women use a norm of care and responsibility for others rather than a norm of justice in solving moral dilemmas (Gilligan 2003). In addition, considering the fact that the moral dilemmas present in her research were real, i.e., they were real experiences of respondents, whereas Kohlberg's dilemmas were abstract, she found yet another empirical argument in favour of her approach. In consequence, she took into account both orientations in the course of building the theory of moral reasoning. The orientation towards justice is based on using external standards, on forming expectations that are considered objective and applying them while judging others, and solving moral problems in everyday life. It is a macrosocial orientation, typical 
of institutional life. Orientation towards care, on the other hand, is focused on empathy, relying on feelings and emotions, as well as responsibility for others in everyday life and in solving moral dilemmas (Rest, Narvares, Bebeau, Thoma 1999). The precedence of personal attitudes towards others over external standards that are considered objective makes us consider this ethics as microsocial and useful in interpersonal relations (Czyżowska 2012). Such a division into micro and macro-worlds obviously works only in theory, and people reveal both orientations in different situations, in accordance with their own preferences in this respect.

Heading towards the problematization of our research, what should be emphasised is that dealing with ethical orientations as a variable that works in teachers' area of educational self-efficacy is justified in the ethical nature of individual educational situations, but also in the context of the functions of the education system, as it is an emanation of the social system. Thus, teachers' ethical orientation creates a climate for assessment, pupils' behaviour at school, the interaction between teachers and pupils, as well as between pupils themselves. This climate might provide a reverse modification of teachers' self-efficacy, which is based on their previous experience. This is why we would like to enquire about the relationship between variables.

\section{Methodology}

The demonstrated empirical research was conducted in the quantitative strategy, in the quasi-experimental design, as theoretical and exploratory research. We have been deliberating about the differences in the average results of the test that measures teachers' educational self-efficacy, depending on their ethical orientation demonstrated and revealed in the test. We placed the research with such problematization in the one-way ANOVA model (with the estimation of ETA variance), in which the role of the fixed variable was played by the result in the test of ethical orientations, whereas the random variable resulted from the teachers' self-efficacy result. From a group of respondents with a diagnosed ethical orientation we selected 51 people who clearly represented orientation towards care and justice, only to compare their results in a test measuring self-efficacy.

The collection of data was facilitated by the Slovak language and psychometric version of the Ethical Orientation Test (TOE). The original Polish version was created by M. Chomczyńska-Rubacha and K. Rubacha (2013 p.241, 2014 pp.79-86) from five stories of ethical conflicts in which their protagonists were involved. The respondents select solutions to those conflicts from a pool of possibilities 
and their choices contain coefficients of orientation towards care and justice. The Slovak adaptation, which is of temporary and working nature, was prepared by the authors of this article. The discriminatory power of all test positions, which was in the range of 0.74-0.9, was verified (estimated on the basis of 126 measurements). We used the same data to calculate the Spearman-Brown correlation coefficient, as an indicator of the test reliability. We obtained $\mathrm{r} t \mathrm{t}=0.75$. We do not know the accuracy of the Slovak version of the test yet. For this reason we are temporarily drawing on the accuracy of the Polish TOE (Chomczyńska-Rubacha, Rubacha 2013, p. 241). The brackets indicating a given orientation were determined with the median test.

We measured educational self-efficacy with the use of the Slovak version of a Polish tool composed of three tasks with a four-level answer scale. The tasks contained descriptions of an educational situation based on a difficult disciplinary problem. The respondent was expected to make a judgement on how to positively solve a given problem. They had a four-level answer scale at their disposal. The average result from all positions was the basis for qualifying a respondent for a given level of educational self-efficacy. The tool had a verified diagnostic accuracy based on the coefficient of the concurrence of competent judges. The discriminatory power of individual positions, measured with the biserial coefficient amounted to: $0.53 ; 0.67 ; 0.79$. This method is one of the situational testing methods and is a classic micro-analytical test in the Bandurian sense.

\section{Results}

All respondents were asked to fill in a self-efficacy measurement questionnaire. Their results, as demonstrated in Table 1, are similar to the normal distribution with minimum asymmetry towards low results. The mean is variable in its structure, which makes it more reliable.

Table 1. Descriptive statistics for self-efficacy

\begin{tabular}{cccccccc}
\hline $\begin{array}{c}\text { Random } \\
\text { variable }\end{array}$ & N & Min. & Max. & Mean & $\begin{array}{c}\text { Standard } \\
\text { deviation }\end{array}$ & Obliquity & $\begin{array}{c}\text { Obliquity } \\
\text { standard error }\end{array}$ \\
\hline Self-efficacy & 102 & 1.00 & 3.00 & 1.9902 & .78972 & .017 & .239 \\
\hline
\end{tabular}

Source: own study.

It points out to the fact that teachers do not constitute a group of very low self-efficacy, but on the other hand, they do not decisively anticipate success of 
their own actions. This probably follows from internal complexity and external conditions of their professional role. Without clearly defined criteria for perfection in the situation of conflict of many expectations, including parents, pupils, and social organisation, it is difficult to maintain self-efficacy on a high level, even if it is based on a positive self-assessment and rewarding professional experience. Similarly, the measure of success is not entirely unambiguous, as the complexity of nearly all educational situations leads to an ambivalent acceptance of each professional success. However, this characteristic is inherently ingrained in the role of the teacher. The maintenance of discipline may, on the other hand, cause disappointment with pupils' decreased creativity. Conversely, by focusing on stimulating creative activity, one may experience an inability to maintain discipline in class. However, does the dominant ethical orientation in the teacher's reasoning differentiate self-efficacy? The results of the discussed study prove that the answer is affirmative, but in favour of the orientation towards justice. Tables 2 and 3 authenticate (homogeneity of variances) the conducted analyses which indicate that the F coefficient is statistically significant at the adopted level (alpha=0.95).

Table 2. Homogeneity of variances test

\begin{tabular}{cc|cc}
\hline Levene's test & df1 & df2 & Significance \\
\hline .036 & 1 & 100 & .849 \\
\hline
\end{tabular}

Source: own study.

Table 3. One-way ANOVA

\begin{tabular}{lccccc}
\hline & Sum of squares & df & Mean square & F & Significance \\
\hline Between groups & 2.833 & 1 & 2.833 & 4.710 & .032 \\
\hline Inside groups & 60.157 & 100 & .602 & & \\
\hline Total & 62.990 & 101 & & & \\
\hline
\end{tabular}

Source: own study.

The teachers who follow the ethics of justice obtained the average self-efficacy of 2.16 (deviation of 0.78 ), whereas the average of those oriented towards care was 1.82 (deviation of 0.76 ), which is demonstrated by Graph 1.

In an attempt to interpret the obtained results, we will refer to the conceptualisation of both variables which constituted a basis for the study, as well as to the knowledge of praxeology, which attempts at the explanation of the reality of 


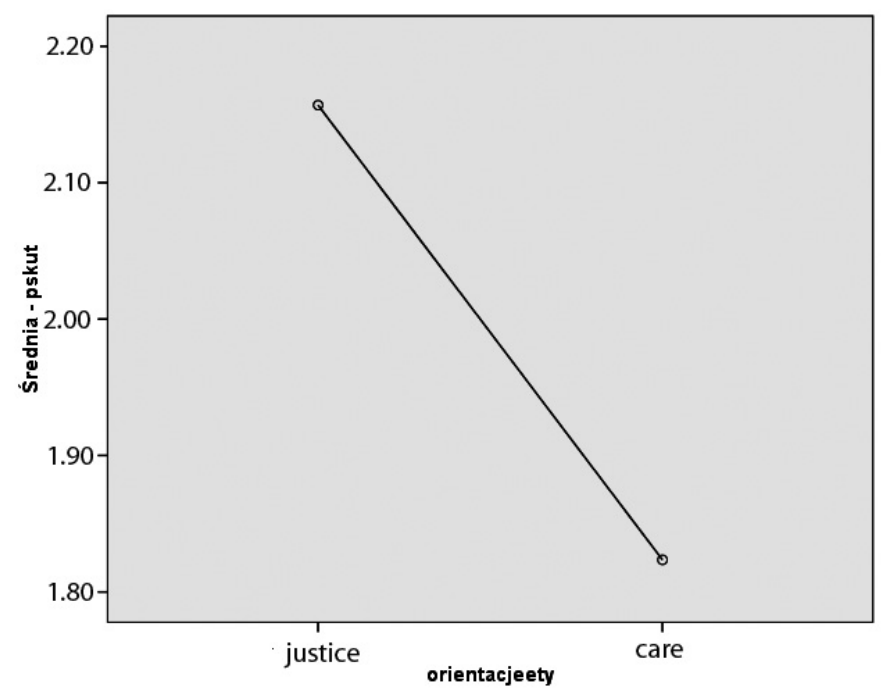

Graph 1. Ethical orientations versus self-efficacy Source: own study.

school interactions. Ethical orientations, which may be interpreted on the basis of how teachers act, especially in problem-solving situations or solving pupils' moral dilemmas, constitute the climate of the school's everyday life. If teachers follow the norm of justice, the climate of school relationships that they create may be viewed by pupils as predictable. Predictability, on the other hand, is one of the elements of the sense of stability and certainty which accompany the everyday school assessment. Perhaps this feeling accompanies not only the beneficiaries of just evaluation, but also those who have little reason to rejoice. It is such behaviour of the teacher which contains feedback whose significance is supported by the norm of justice. The teacher's assessment, behaviour, and interactions that teem with justice contribute to the formation of an environment in which everyone knows what to do in order to be accepted. The reason for the loss of acceptance is also known. A school climate in such a delineation describes democratic, but probably also egalitarian environments for education and discipline. On the other hand, the ethics of care, from the same point of view, is linked to unpredictability, uncertainty and the lack of clearly defined criteria of pupil perfection. In this situation also weaker pupils who cause discipline problems may be appreciated. Teachers who apply the ethics of care are more inclined to reward in a way that 
is dependent on emotional attitudes, and on criteria that are not communicated to everyone. These criteria are surprising and they do not generate the feeling of acting in a clearly defined disciplinary situation. The outlined vision is not complete, but yet we should stick to it for the sake of preserving the clarity of our interpretation. Moving now to the conceptualisation of teachers' self-efficacy, let us look into what is formed in their consciousness and emotions as a result of the formation of an environment based on justice and care. In the former case, we may expect that the climate of justice and clarity of teachers' acting and evaluation allows the teachers themselves to have emotional and cognitive comfort. The conceptualisation of our random variable shows that such experiences build strong self-efficacy (Bussey, Bandura 1999). However, experiencing the effects of the dominance of the ethics of care may weaken self-efficacy, as teachers become 'victims' of an unpredictable educational environment (Łukaszewski, 1984). This in turn generates negative perception of one's own professional experience, and as a consequence it enfeebles self-efficacy.

As we have above defined the idealisation of school reality which follows from the conceptualisation of ethical orientations and self-efficacy, let us now try to move to the practice of school interactions. It perhaps cannot be claimed that environments based on the norm of justice generate educational effects which are only positive, whereas environments based on the norm of care create only negative environments. Nor can we state that there exclusively exist environments that are pure in terms of this dimension of teachers' ethics. School is a place where many teachers work. Norms of justice may not account for complex educational cases, because they are general in nature. Being just may in some situations mean being insensitive and ruthless. On the other hand, being caring may have to mean being unjust in some cases, but sensitive and empathic at the same time. From the point of view of praxeology, it is only this peculiar mixture of consequence of both orientations that builds the climate of the school and the interactions within it. However, our study results show that for educational self-efficacy, orientation towards justice seems to be more valuable. Perhaps we have achieved this effect on account of a theoretical location of self-efficacy, or perhaps, which may be beyond our consciousness, as an effect of a larger number of more subjective factors than those which our research method was sensitive to. In a nutshell, as is always the case with a quantitative strategy, when trying to determine regularities we do not reach that part of the result which is not corroborated by the variance of regularity. Our Eta amounts to 0.21 and this is the true strength of this relationship. 


\section{References}

Bandura A. (1994). Self-efficacy: Toward a unifying theory of behavioural change, in: R.F. Baumeister (ed.), The self in Social Psychology, Ann Arbor Press.

Bussey K., Bandura A., (1999) Social cognitive theory of gender development and differentiation, „Psychological Review” 4.

Chomczyńska-Rubacha M., K. Rubacha (2006), Poczucie własnej skuteczności nauczycieli.. Podstawy teoretyczne, pomiar i obszary badań."Przegląd Badań Edukacyjnych" 2(3) .

Chomczyńska-Rubacha M., Rubacha K. (2013) Ethical orientation and sex in teachers with varied educational strategies. “The New Educational Research" Vol. 33 No 3.

Chomczyńska-Rubacha M., Rubacha K. (2014) Ethical orientation of men and women in early, middle and late adulthood. "Edukacja Dorosłych" no. 1.

Czyżowska D.(2012) Sprawiedliwość I troska. O sposobach rozwiązywania dylematów moralnych przez kobiety i mężczyzn. Wydawnictwo Uniwersytetu Jagiellońskiego. Kraków .

Gilligan C. (1998) Remembering Larry. Journal of Moral Education Vol. 27, No. 2.

Gilligan C. (2003) In a different voice. Psychological theory and women`s development. Harvard University Press. Cambridge, Massachusetts and London, England.

Kohlberg L. (1984), The psychology of moral development. San Francisco CA, Harper \& Row.

Łukaszewski W. (1984), Szanse rozwoju osobowości, [Chances of personality development] PWN Warsaw.

Michel W., Schoda Y., Peake P., (1988) The mature adolescent competencies predicted by preschool delay of gratification, "Journal of Personality and Social Psychology" 54.

Pervin L.A., John O.P. (2002) Osobowość - teorie i badania. Wydawnictwo UJ Kraków. Rest, J.R., Narvaez, D., Bebeau, M. \& Thoma, S. (1999). Postconventional Moral Thinking: A Neo-Kohlbergian Approach. Mahweh, New Jersey: Lawrence Erlbaum Associates. 